Review

\title{
Sustainable Water Management in Urban, Agricultural, and Natural Systems
}

Tess Russo ${ }^{1,2, *}$, Katherine Alfredo ${ }^{1}$ and Joshua Fisher ${ }^{3}$

1 Columbia Water Center, Columbia University, 500 W 120th Street, New York, NY 10027, USA; E-Mail:ka2491@columbia.edu

2 Department of Geosciences, The Pennsylvania State University, 310 Deike, University Park, PA 16802, USA

3 The Advanced Consortium on Cooperation, Conflict, and Complexity (AC4), Columbia University, 475 Riverside Dr. \#253, New York, NY 10115, USA; E-Mail: jf2788@columbia.edu

* Author to whom correspondence should be addressed; E-Mail: russo@psu.edu or tr2378@columbia.edu; Tel.: +1-814-865-7389.

External Editor: Miklas Scholz

Received: 21 October 2014; in revised form: 22 November 2014 / Accepted: 27 November 2014 / Published: 12 December 2014

Abstract: Sustainable water management (SWM) requires allocating between competing water sector demands, and balancing the financial and social resources required to support necessary water systems. The objective of this review is to assess SWM in three sectors: urban, agricultural, and natural systems. This review explores the following questions: (1) How is SWM defined and evaluated? (2) What are the challenges associated with sustainable development in each sector? (3) What are the areas of greatest potential improvement in urban and agricultural water management systems? And (4) What role does country development status have in SWM practices? The methods for evaluating water management practices range from relatively simple indicator methods to integration of multiple models, depending on the complexity of the problem and resources of the investigators. The two key findings and recommendations for meeting SWM objectives are: (1) all forms of water must be considered usable, and reusable, water resources; and (2) increasing agricultural crop water production represents the largest opportunity for reducing total water consumption, and will be required to meet global food security needs. The level of regional development should not dictate sustainability objectives, however local 
infrastructure conditions and financial capabilities should inform the details of water system design and evaluation.

Keywords: sustainable water management; sustainability evaluation; urban water systems; irrigation; ecosystem water requirements; water reuse

\section{Introduction}

Water is at the foundation of sustainable development as it is the common denominator of all global challenges: energy, food, health, peace and security, and poverty eradication.-UN Water [1]

\subsection{Definitions}

Sustainable development is commonly defined by the Brundtland Report [2] as meeting the needs of the present generation without compromising the ability of future generations to meet their own needs. "Needs" include economic, environmental and ecosystem service delivery, and cultural goals including identity and subjectively defined values. Together, these are commonly referred to as the sustainability triple bottom line. Sustainable development is the combination of sustaining the natural environment, resources, and community, and development of the economy and societal goals.

Sustainable water management (SWM) is a critical component of sustainable development, and accounts for similar issues as sustainability. Mays [3] defines SWM as meeting current water demand for all water users without impairing future supply. More specifically, SWM should contribute to the objectives of society and maintain ecological, environmental, and hydrologic integrity [4]. The definition proposed by Alley et al. [5] for groundwater management cites protection of the components in the sustainability triple bottom line: environment, economy, and society. A more holistic objective is provided in Agenda 21 [6] which ensures that "adequate supplies of water of good quality are maintained for the entire population of the planet, while preserving the hydrological, biological and chemical functions of ecosystems, adapting human activities within the capacity limits of nature and to combat vectors of water-related diseases."

Definitions of SWM present challenges for adoption because of the widespread use of subjective language and lack of detail. Most definitions offer only a broad conceptualization of the sectors or environments to consider. The language in most SWM definitions is usually qualitative and often normative. For example, sustainability entails "the design of human and industrial systems to ensure that humankind's use of natural resources and cycles does not lead to diminished quality of life due either to losses in future economic opportunities, or to adverse impacts on social conditions, human health, and the environment" [7]. This definition uses "diminished quality of..." and "adverse impacts on..." to describe thresholds of sustainable system effects, which are difficult to interpret for management purposes. With respect to sustainable urban water management in Agenda 21 from the United Nations, Larsen \& Gujer [8] assert that no concept proposed is applicable in practice. The normative guidance of most sustainability definitions is especially problematic for policy makers and water managers who are motivated to adopt sustainable practices, but have little tangible support. 


\subsection{Integration of Sustainable Development and Sustainable Water Management}

Sustainable development and SWM are inherently related due to the requirement of water for development [9,10]. Water is a fundamental requirement for human life and well-being, thus proper management of water is a means to improve food production, reduce poverty and water-related diseases. SWM involves allocating water between competing purposes and users. This allocation can be represented as a hierarchy, similar to Maslow's hierarchy of human needs (Table 1) [11]. The framework asserts that the foundational biophysical needs must be met before effort can be dedicated to fulfilling higher needs. The second level of Maslow's hierarchy is "safety", which translates to security of domestic water and agricultural production at the local level. The third and fourth levels of needs in this hierarchy, "social" and "esteem", correspond to broader community water services and a focus on maintenance, justice, and responsibility, respectively. The two hierarchies share commonalities from levels 1 to 4, and seemingly end at the fifth level. Maslow's inward-looking "self-fulfillment" contrasts with resource sustainability, which emphasizes an outward-looking perspective including the fulfillment of other users both now and in the future. The greatest challenge for developing countries is promoting SWM, the fifth and final need, while still working to address their foundational needs.

Table 1. Comparison of Maslow's hierarchy of human needs and the hierarchy of water management needs. Adapted from Melloul and Collin [11].

\begin{tabular}{ccc}
\hline Level & Maslow's Hierarchy of Human Needs & Hierarchy of Water Management Needs \\
\hline 5 & Self-fulfillment & Water resource sustainability \\
\hline 4 & Esteem (status, recognition) & $\begin{array}{c}\text { National water projects } \\
\text { (supply, remediation, public awareness) }\end{array}$ \\
\hline 3 & Social (family, community) & $\begin{array}{c}\text { Regional water projects } \\
\text { (supply, treatment plants) }\end{array}$ \\
\hline 2 & Safety (security, stability, law, order) & $\begin{array}{c}\text { Local development (agriculture, domestic } \\
\text { water, water quality standards) }\end{array}$ \\
\hline 1 & Physiological for survival & $\begin{array}{c}\text { Biophysical individual needs } \\
\text { (water for survival) }\end{array}$ \\
\hline
\end{tabular}

This review explores urban, agricultural, and natural water system management in developing and developed nations. We aim to address the following questions: (1) How is SWM defined and evaluated? (2) What are the challenges associated with sustainable development in each sector? (3) What are the areas of greatest potential improvement in urban and agricultural systems? And (4) What role does country development status have in SWM? The first question is addressed generally in Sections 1 and 2, and more specifically with examples in Section 3. Questions (2)-(4) are addressed in Sections 3 and 4, and are summarized in Tables 2-4. Limitations to this review are discussed in Section 4.3. Rather than providing exhaustive discussion on all aspects of water management, the objective of this study is to conceptualize the dialogue around what constitutes SWM practices according to three sectors: urban, agricultural, and natural systems. Municipal and agricultural water use account for over $80 \%$ of global human water use, and higher in many developing nations [12]. The number of people experiencing perennial water shortages in urban areas is expected to increase from 150 million (ca. 2000) to 993 million by 2050, and those experiencing seasonal water shortages will rise from 1 to 3.1 billion, 
respectively [13]. Agricultural water use accounts for $70 \%$ of global water consumption, and can exceed $90 \%$ in developing nations. Water management of natural systems is a key requirement of sustainable urban and agricultural management practices. These three sectors represent the majority of water use globally, but may not constitute the majority of water use in a specific region or country (e.g., Canada, Russia, and the United Kingdom). Therefore, a more detailed study of SWM should be completed at the regional scale to provide the most relevant information for management and policy purposes.

Table 2. Primary sustainable water management objectives.

\begin{tabular}{|c|c|c|}
\hline Sector & Developing Areas & Developed Areas \\
\hline Urban & $\begin{array}{l}\text { - Equitable delivery } \\
\text { - Reliability } \\
\text { - System flexibility with growth }\end{array}$ & $\begin{array}{l}\text { - Supporting demand } \\
\text { - Infrastructure longevity } \\
\text { - Recycling and reuse } \\
\text { - Environmental protection }\end{array}$ \\
\hline Agriculture & $\begin{array}{l}\text { - Food security } \\
\text { - Expansion of irrigated area } \\
\text { - Supplemental irrigation } \\
\text { - Crop water productivity }\end{array}$ & $\begin{array}{l}\text { - Crop water productivity } \\
\text { - Environmental protection } \\
\text { - Resource conservation }\end{array}$ \\
\hline Ecosystem & - Protection of valued ecosystem services & $\begin{array}{l}\text { - Protection and/or restoration of natural } \\
\text { functions within development constraints }\end{array}$ \\
\hline
\end{tabular}

Table 3. Developing country challenges and solutions for sustainable water management in urban, agricultural, and natural systems.

\begin{tabular}{|c|c|c|}
\hline Sector & Challenges & Examples $^{+}$ \\
\hline Urban & $\begin{array}{l}\text { - Intermittent operation } \\
\text { - Lost or stolen water } \\
\text { - Rapid urban growth } \\
\text { - Political conflict } \\
\end{array}$ & $\begin{array}{l}\text { - India [14], Ethiopia [15] } \\
\text { - Palestine [16] } \\
\text { - China }[17] \\
\text { - } \text { Mid East }[16,18,19]\end{array}$ \\
\hline Agriculture & $\begin{array}{l}\text { - Irrigation infrastructure cost } \\
\text { - Subsidies promoting irresponsible use } \\
\text { - Low water use efficiency }\end{array}$ & $\begin{array}{l}\text { - Sub-Saharan Africa [20] } \\
\text { - India [21] } \\
\text { - } \quad \text { Africa [22]; China, Pakistan [23] }\end{array}$ \\
\hline Ecosystem & - Economic development priorities & - India [24] \\
\hline Sector & \begin{tabular}{|c|} 
Solutions \\
\end{tabular} & $\begin{array}{c}\text { Examples } \\
\end{array}$ \\
\hline Urban & $\begin{array}{l}\text { - Institutional improvements } \\
\text { - Low-tech water capture and treatment* } \\
\text { - Graywater reuse * } \\
\text { - Cooperation, sharing riparian rights } \\
\text { - Stakeholder engagement }\end{array}$ & $\begin{array}{ll}\text { - } & \text { Algeria [25]; Palestine [26] } \\
\text { - } & \text { Greece [27] } \\
\text { - Jordan [28] } \\
\text { - } \text { Mid East [29]; World [30] } \\
\text { - Mexico [31]; World [32] } \\
\end{array}$ \\
\hline Agriculture & $\begin{array}{l}\text { - Optimize water productivity } * \\
\text { - Improve subsidy/pricing structure } \\
\text { - Supplemental irrigation } \\
\text { with rainwater harvesting } \\
\end{array}$ & $\begin{array}{ll}\text { - } & \text { World }[33,34] \\
\text { - India [35]; Mid East [36]; World [37] } \\
\text { - Sub-Saharan Africa [38,39]; Burkina } \\
\text { Faso [40]; Drylands }[41]\end{array}$ \\
\hline Ecosystem & - Communication of ecosystem service value & - Africa $[42,43] ;$ Ethiopia [44] \\
\hline
\end{tabular}

Notes: ${ }^{+}$Regions and non-country area descriptions are in italics; * Topics covered in the discussion. 
Table 4. Developed country challenges and solutions for sustainable water management in urban, agricultural, and natural systems.

\begin{tabular}{|c|c|c|}
\hline Sector & Challenges & Examples $^{+}$ \\
\hline Urban & $\begin{array}{l}\text { - Demand management } \\
\text { - Cost of adopting new technology }\end{array}$ & $\begin{array}{l}\text { - Australia [45]; USA [46] } \\
\text { - World [47] }\end{array}$ \\
\hline Agriculture & $\begin{array}{l}\text { - Over-allocation of water resources } \\
\text { - Cost of new technology } v \text { s. low cost of water }\end{array}$ & $\begin{array}{l}\text { - S Africa }[48] \\
\text { - USA }[49,50]\end{array}$ \\
\hline Ecosystem & - Development priorities & - World [51] \\
\hline Sector & Solutions & Examples \\
\hline Urban & $\begin{array}{l}\text { - } \text { Conservation education } \\
\text { - Water reuse and recycling * } \\
\text { - Stormwater management, green infrastructure * }\end{array}$ & $\begin{array}{l}\text { - S Africa [52]; Australia [53] } \\
\text { - World [54]; UK [55] } \\
\text { - UK [56]; Denmark [57] }\end{array}$ \\
\hline Agriculture & $\begin{array}{l}\text { - Improve water allocation, irrigation management } \\
\text { - Affordable precision agriculture methods * }\end{array}$ & $\begin{array}{l}\text { - Greece [58]; Spain [59] } \\
\text { - USA [49] }\end{array}$ \\
\hline Ecosystem & $\begin{array}{l}\text { - Identification and protection of } \\
\text { most valuable resources } \\
\text { - Definition of a degradation tolerance level }\end{array}$ & $\begin{array}{ll} & \mathrm{USA}[60] \\
\text { - } & \text { World }[61]\end{array}$ \\
\hline
\end{tabular}

Notes: ${ }^{+}$Regions and non-country area descriptions are in italics; * Topics covered in the discussion.

\section{Evaluation Tools and Models}

Sustainable systems are especially apt to compare favorably with conventional systems when the comparison includes a full cost accounting of the environmental and public health harms and benefits of each system.- - Horrigan et al. [62]

SWM evaluation requires accounting for real costs, opportunity costs, and competing requirements among and within water use sectors. These sometimes include vague political and socio-economic components, which often do not translate easily to the quantitative values necessary for planning, decision-making, and rigorous monitoring and assessment. Evaluation models range from generic indices used to compare management practices across multiple agencies and environments, to site-specific modeling analyses that enable individual managers and governments to assess progress toward or away from sustainable practices [63].

Inputs to the evaluation should be quantifiable, independent from each other, unambiguous, and representative. Quantitative evaluations allow for assessing conditions and comparing management options. Following the definitions for sustainable development, many tools aim to evaluate environmental, social, and economic aspects of the system [64,65]. While many such tools quantify environmental impact and resource utilization, we continue to lack robust quantitative evaluation methods for social-cultural criteria, and the interconnected impacts of social, biological, and physical components of complex systems [66,67].

In addition to having a quantitative framework that bridges a complex system, evaluation models must account for the time and place dependent conditions of sustainability. Time is relevant within the lifecycle of a specific action or management practice, and also in the subsequent impacts on the environment. The spatial scale of evaluation governs what resources are assumed to be available for a given location, ranging from household to village to watershed to country to multinational region. 
The spatial extents of the region, including quantity of available water resources and competing users, will influence analysis of existing and potential development. Accounting for local conditions and perspectives in the evaluation method has particular utility when assessing policy impacts over time or when advocating for specific policy changes [25].

There are three primary evaluation methods for SWM: (1) indicators and indices; (2) product related assessment; and (3) integrated assessment [64]. Water indicators and indices should simplify, quantify, and communicate information [68]. The classification, weighting, and method of index aggregation varies by model [68], making the processes somewhat arbitrary. However, the advantage of the indicator method is a simple numerical result that provides comparative capability across cases. Common indices which address water in sustainable development include the Water Poverty Index [69], the Canadian Water Sustainability Index [70], the Environmental Performance Index [71], and the Watershed Sustainability Index [72]. Water management indicators typically include water infrastructure, environmental quality, economics and finance, institutions and society, human health, and technology [4]. Other indices which specifically address some of the socio-economic dilemmas mentioned previously include accessibility of data, institutional schemes to resolve water conflict, and democratic water-related decision making [3].

Product related assessments, or life cycle assessments (LCA), can provide information about land, water, and energy requirements for a physical system or supply chain. The LCA framework can be used to inventory a set of sustainability indicators across the supply chain of a water system. Examples such as the Ecological Footprint [73] and its hydrologic corollary, the Water Footprint [74], translate biophysical assets into progress measurements. These tools are resource accounting mechanisms that enable integrated quantitative assessments of land and water resources in terms of current and potential demand, and regenerative probability at national and global scales.

Integrated assessments tend to be holistic assessments completed using system dynamics models, risk analysis, cost-benefit analysis, and impact assessments. Integrated assessments provide a systems perspective, often incorporating more robust quantification than the indicator method alone. Information theory can be used to study how efficiently human systems are using resources, and the resilience of those systems [75]. A systems dynamics modeling approach can be used with a framework based on viability loops to monitor water system acceptance, use, and economics [76]. Chung and Lee [77] demonstrate the value of coupling a hydrologic model and a multi-criteria decision model (MCDM) to evaluate alternatives for sustainable development. Many of the integrated assessment methods can include a Monte Carlo method to test for uncertainty and sensitivity.

Beyond the three typical evaluation types, groundwater use is often evaluated by comparing extraction to the aquifer safe yield. Historically, groundwater extraction sustainability was based only on groundwater recharge, which over-simplified subsurface dynamics. Early definitions of safe yield preclude pumping that is "dangerous" [78] or produces an "undesirable result" [79], including rapid declines in groundwater levels. More recent studies have called into question both the value and the sustainability of safe yield [80-82]. Evaluations of groundwater development sustainability account for natural groundwater recharge rates, as well as capture which includes induced recharge and decreases in natural discharge $[5,83,84]$. Advances in numerical and statistical models are improving our estimates and projections of groundwater use sustainability. 
The diversity of evaluation methods described above provides water users and managers a wide array of tools to assess the sustainability of water use and allocation in specific water systems at a variety of scales. These tools reflect the complexity of evaluating sustainability within the physical and social world. Local variations, data availability, and socio-political objectives may lead to selection of different water quantity sustainability evaluation methods. This is particularly relevant for setting estimates of thresholds for sustainable use and allocation. Future work will improve evaluation frameworks in terms of measuring and assessing SWM including spatial and temporal efficiency, supply longevity, and equitable distribution.

\section{Sector Reviews}

\subsection{Developing Countries: Practices, Challenges, and Solutions}

\subsubsection{Urban Water Development}

Access to potable water is among the most important prerequisites for healthy and productive development. Water and socioeconomic development are integrally connected - either creating a vicious downward spiral or reinforcing positive development practices [85]. Sustainable development in urban areas requires reliable, equitable, and easily accessible water (Table 2). Providing water to the rapidly growing urban populations in developing nations creates a complex logistic and economic problem. This is exacerbated in areas where urban expansion is largely informal an unplanned, as demand is difficult to project and consumption is difficult to monitor.

Indicator methods are commonly used for evaluating urban water management. Developing successful indicator methods requires continued efforts to quantify the relationships between urban water management and environmental sustainability, which groups including the UN Centre for Human Settlements and the UN Environmental Program are currently pursuing. Monitoring and evaluation of urban water systems in developing regions will help improve current conditions and inform future development. One assessment evaluated 25 indicators in four criteria groups: technical, social/environmental, financial, and institutional [86]. They found that technical (design flow and the functionality of the system) and social criteria (status of use, equity, decision making in operations and maintenance) are more crucial to sustaining a water system than financial and institutional criteria, although all are necessary.

Urban water system sustainability faces challenges emerging from physical resource, infrastructure, and socioeconomic conditions (Table 3). In water rich regions, water distribution systems are optimized to meet a specified minimum pressure, whereas in water stressed regions equal water distribution among users is the goal. In the latter case, distribution systems should be designed with the expectation of intermittent operation rather than assuming continuous supply, thus reducing pressure problems and inequities in distribution [14]. Both water rich and poor regions are faced with the infrastructure design and water supply challenges of meeting demands associated with population growth [17]. Infrastructure and operation problems include leaking pipes and "stolen" water in water scarce regions. Material and construction failures, electricity supply or operation and maintenance issues all affect water distribution. Thirty percent of water supply systems serving rural sub-Saharan communities are non-functioning at 
any given time [15]. Challenges include infrastructure issues, however their origins may include socio-institutional problems involving responsibility, knowledge, and coordination [87].

Regional conflict presents a significant challenge to SWM, especially in countries with differing development levels. Melloul and Collin [11] give an example where two factions of a local population are at different stages of the Water Management Hierarchy of Needs (Table 1). These disparities led to conflicts concerning resource allocation and development plans. Political conflict often leads to increased water stress, and vice versa. The UN has numerous programs involved in assessment and management of water resources, including transboundary integrated water resources management and urban water supply [88]. Recent evaluations of cooperation and competition in transboundary water management show a clear preference for cooperation rather than conflict among riparian neighbors [29,30].

Increasingly, sustainability solutions include participatory planning and water capture and reuse. Sustaining a water system requires personnel training, monitoring, health and safety regulations, and communication with users [25]. Sustainable water utilities should involve the population which they serve, and utilize the local knowledge of water resources and traditional management practices [89]. The inclusion of women in water management decisions is particularly important in cultural contexts where women are traditionally charged with collecting water for domestic consumption and use, as water management can have immediate and long-term impacts on gender equality [85,90].

Water capture, storage, and reuse are becoming common aspects of SWM systems [91]. While traditional capture and treatment systems may be cost-prohibitive for many developing regions, there are low-cost, low-technology treatment systems including constructed wetlands or layering with indigenous rock materials which can be effective for treating water for reuse [27,92,93]. Local conditions and capacity for operation require evaluation to determine the feasibility on a site by site basis [94]. Reuse of graywater in urban areas is becoming more common in water stressed, developing regions [28]. Decentralized systems are recommended at the household or neighborhood scale for producing recycled water for gardening or domestic reuse.

\subsubsection{Agricultural Water Development}

Food production is an integral part of sustainable human development. Sustainable agricultural water management objectives include attaining food security and maximizing food water productivity in rainfed and irrigated agriculture (Table 2). A majority of global population growth is occurring in developing countries, some of which rely heavily on rainfed agriculture. Therefore, rainfed agriculture must expand and/or see increased productivity to feed the growing population [95]. Irrigation provides a water supply buffer during dry periods, reducing the risks to purely rainfed agriculture. Though irrigation led to notable production gains in India and China over the past decades, it was coupled with increased dependency on unrenewable water resources in many regions.

Quantification of agricultural practice impact on water resources will help prevent these negative impacts under future development. Pereira et al. [34] present case studies for Tunisia and China using an indicator method for evaluating agricultural management strategies. Their framework accounts for water reuse and crop production economics. Dixon and Wood [44] used optimization of social, environmental, and economic benefits to define agricultural plans. While leaving natural areas uncultivated was environmentally sustainable, it provided little support for human development. 
The optimization method recommended mixed use: leaving part of the land in its natural condition, and converting part of it for cultivation. Despite the demonstrated success, optimizing agricultural development and environmental water resources is not typical.

Few of the Green Revolution nations prioritized sustainable agricultural water use with increasing yields and meeting food security goals. Therefore, while the Green Revolution more than doubled crop yields, resulting in greater food security, lower food prices, and improved social and economic conditions [96], it also had many unintended environmental consequences. Government subsidies for water and energy (for pumping water) have led to wider adoption of irrigation and higher crop yields, however the low costs provide little incentive for farmers to conserve water and adopt more efficient irrigation methods. In many agricultural regions, greater than $100 \%$ of the renewable water resources are used for irrigation each year [97]. These regions must assess alterative irrigation support policies and agricultural water management strategies in order to sustain production in the future [21].

Solutions include improving water productivity and reducing risk in rainfed crops by using supplemental irrigation (Table 3). Postel [33] suggests a transition from Green Revolution to Blue Revolution, where productivity is measured in crop production per unit water. In much of the developing world, irrigation systems are less than $50 \%$ efficient. Increasing irrigation productivity requires improvements to technical, managerial, institutional, and agronomic methods. In rainfed agricultural regions, improvements in rainwater capture, selection of drought-resistant crops, and alternate tillage practices will be critical to feeding growing populations [22]. Using rainwater harvesting for supplemental irrigation to mitigate the impact of dry spells, combined with soil fertility management, can more than double rainfed crop yields $[38,40]$. Though the practice is not broadly used, there is widespread potential for water harvesting for supplemental irrigation in many rainfed agricultural regions $[39,98]$.

\subsubsection{Environmental Protection}

Evaluation of environmental sustainability is required concurrently with development planning to protect ecosystem services (Table 2). Integrated modeling is a common approach for evaluating impacts between the human and natural environments. For example, integrated modeling can be used to assess the impact of rainwater harvesting and storage on downstream hydrology and environmental conditions [99]. Application of this model can reduce conflicts between upstream and downstream water stakeholders, while maintaining environmental flow requirements. A case study in northern India demonstrates a progressive water resource development plan to evaluate conservation of land, water, and forest resources [24]. Their proposed plan considers ecological sustainability, socio-economic options and user requirements. An important and uncommon component of their proposed plan is ensuring income generation where land use change will affect employment options. This is critical given the emphasis on land conservation and restoration in an area where $77 \%$ of the population depends on agriculture for income, similar to much of the rural developing world.

An effective method to encourage conservation and land protection is communicating the economic value of natural resources $[42,44]$, thus allowing a community to make the optimal development decision (Table 3). Communities that depend heavily on the natural environment for their livelihoods innately place a high priority on sustainable use of resources and protection of the environment [43]. Quantifying 
ecosystem value makes it simple to determine whether a use scenario protecting water resources is most beneficial for stakeholders.

Relatively few studies explore sustainable human development and water in the natural environment in developing countries, with the exceptions of the examples above, the Millennium Ecosystem Assessment report [10], and the bi-annual release of the Environmental Performance Index [71]. The priority for many developing regions is meeting present basic needs, which, according to the Water Management Hierarchy (Table 1), must be addressed prior to planning for a sustainable future. Generally, protection of the environment is not integrated into policy as it is considered anti-development. To reduce the risks of this policy omission, the Southern African Development Community has adopted the fundamental assumption that, "strategies to reduce poverty should not lead to further degradation of water resources or ecological functions and services." They hope to move mainstream sustainability criteria into water resources policy and management, especially in developing nations.

\subsection{Developed Countries: Practices, Challenges, and Solutions}

\subsubsection{Urban Water Development}

Every human being has a right to clean water. For urban areas, our vision is water management where water and its constituents can be safely used, reused and returned to nature.-Hellström et al. [67]

The primary functions of urban water management include meeting hygiene (supply and sanitation), drinking water, drainage, urban agriculture, and recreational needs. Meeting these needs while protecting natural resources and human health, especially if water is scarce, is key to sustainable development [100]. Challenges include water demand management, and the cost of adopting sustainable, innovative technologies (Table 4).

Indicator methods were most common for evaluating sustainable urban water management, similar to the developing country studies. The Sustainable Urban Water Management Program in Sweden uses five categories of sustainability criteria. The criteria include: nontoxic environment, health and hygiene, human resources, natural resources, financial resources, functionally robust and flexible, adaptable to local conditions, and easy to understand to encourage responsible user behavior [67]. The structure of the evaluation framework is modular so it can be used to evaluate cities, structures, and scenarios. Several cities have developed their own sustainability evaluation models, including the Sustainable Index for Taipei and Sustainable Seattle, with 51 and 40 indicators, respectively. Unfortunately, development often leads to some level of environmental or resource degradation. "Sustainable" practices in these cases may be defined as having the least detrimental environmental, economic, and social impacts. For example, to account for continued development in the water-scarce western United States, proposed water policy would use a hierarchical tree of environmental values to direct damage to the least valuable resource [60].

In developed countries where water demand far exceeds sustenance requirements, water demand management becomes relevant. The need for conservation and demand management is a function of resource availability, population growth, and climate change. In addition to technology innovation and pricing incentives, education and awareness are critical to achieving conservation goals. One case study concluded that $50 \%$ of time and resources need to be spent on user education and awareness [52]. 
Marlow et al. [47] review sustainable urban water management methods, and discuss probable barriers including the uncertainty and challenges of innovative technology adoption, financial considerations, and institutional bias or advocacy. Innovative systems may require experimentation and carry inherent risk, so as more cities adopt sustainable practices, sharing experiences and results is required to broaden adoption. The cost of infrastructure and technology improvements may be offset by water prices which reflect its true value.

Future solutions for sustainable urban water management include broader adoption of water reuse and green infrastructure practices. Approaches for improving sustainable water reuse can be categorized into two groups: (1) Substitution (e.g., rainwater capture and reuse of graywater); and (2) regeneration (e.g., potable reuse and wastewater reuse) [54]. Public awareness of treatment practices and cooperation for how treated water can safely be used are key to developing successful reuse programs [53]. In addition to treating and reusing wastewater, stormwater runoff should be viewed as a potential water source, rather than water that needs to be treated and routed away [91]. Ellis [56] advocates for a wider green infrastructure framework including green roofs, downspout disconnection, and canopy cover of $25 \%-30 \%$ in riparian corridors. These broader sustainability practices can improve urban water management, while also reducing energy consumption, and benefiting local ecosystem services.

\subsubsection{Agricultural Water Development}

Agricultural water use accounts for $70 \%$ of worldwide consumption. Irrigation is broadly adopted in developed regions because it supports higher crop yields with lower risk [101]. Similar to developing regions where irrigation is occurring, many aspects of industrial agriculture in the first world are unsustainable [62]. Evaluation of water management in agricultural development must account for inevitable negative impacts on the environment [80,102]. Evaluating the sustainability of irrigation practices requires determining the degree of environmental degradation that people are willing to accept. Metrics for evaluating irrigation systems and on-farm water use practices must account for off-farm (or downstream) consequences. SWAGMAN is a tool that integrates hydrologic, agricultural, environmental, and economic models [103]. The SWAGMAN model helps determine crop types and irrigation methods which increase agricultural value while improving environmental conditions relative to business as usual. Sustainable irrigation practices will always be site specific, depending on local climate, soil, topography, and water source. For example, areas with shallow water tables will need different strategies compared to areas with deep water tables. For the former, water logging and soil salinization may be primary concerns, while energy costs and groundwater depletion are issues for the latter.

Negative environmental impacts due to agriculture are inevitable, but they can be minimized by increasing the efficiency of nutrient additions and water use [104]. There are clear opportunities for improving water productivity in the agricultural sector. Two primary areas include: (1) improving water allocation; and (2) improving application efficiency (Table 4). Improving allocation requires selection of crops which require less irrigation per unit of production, given the local climate and growing conditions. For example, reducing beef production, which requires 100 times the water required to produce equal protein from grains [105], would improve water productivity. Broad improvements in crop water productivity requires a better understanding of the biological, biogeochemical, and ecological processes active in agricultural settings. Improved farm management practices include no-till farming, 
drip or other efficient irrigation technologies, and soil tensiometers or moisture sensors. Many farms in developed nations can afford to use irrigation, though only $\sim 10 \%$ of farmers in the Western U.S. improve their irrigation application timing by using soil monitoring technology which informs irrigation scheduling based on actual conditions and plant requirements [49]. The low adoption rate of precision agricultural technologies is evidence of the cost and implementation barriers faced by farmers. However, as aquifers become depleted, the cost of pumping water from deep aquifers will increase which may make conservation technologies relatively affordable. The solution requires efficient irrigation technologies which are economically preferable to current water use costs.

\subsubsection{Environmental Protection}

Water management must balance development needs with environmental protection or restoration (Table 2). Multiple methods for ecosystem or environmental evaluation have been developed in both applied and academic literatures (e.g., [105-107]). Typical water-related evaluation criteria include stream discharge, groundwater elevation, lake stage, and rates of flow between surface, soil, and groundwater. Some of these criteria have single thresholds for defining sustainable hydrologic behavior, while others have more complicated dynamic requirements. Numerous models can be used for estimating the sustainability of riverine systems in developed watersheds. The framework Ecological Limits of Hydrologic Alteration (ELOHA) is based on the requirement of natural flow variation, i.e., that a single minimum flow threshold is insufficient [108]. The quantity of flow in the river, or the flow regime, can be characterized using look-up tables with hydrologic modeling [109]. In an effort to recreate natural flow variability on a controlled river, statistical methods can be used to compare current flow frequency distributions to a natural reference [110].

Several integrated models aim to identify natural water system vulnerability and value under human development scenarios to help prioritize protection and management (Table 4). Given the natural or desired streamflow regime, the impact of population growth and development can be modeled and used to inform water management practices [111]. When applied over multiple watersheds, results can identify locations where water and growth management strategies are most needed, and where they will provide the greatest benefit. Alternatively, modeling can identify incompatibilities between human and ecosystem requirements, which are then used to develop and test new management strategies [107]. The timing and frequency of incompatibilities must be assessed using both within-year and among multiple year analyses to account for seasonal and long term trends in water supply and demand.

Given that urban and agricultural development will impact environmental systems, defining sustainability requires setting a tolerance level or acceptable pathway. Instead of setting a static goal, Chapin et al. [61] propose a method of ecosystem stewardship that maintains a trajectory which sustains social-ecological systems and ecosystem services. The trajectory may vary over time as conditions change, and actions should be taken to correct undesirable trajectories when they occur. The temporal variability of this method makes it perhaps more difficult to define, however the flexibility is valuable for accommodating population growth and climate change. 


\section{Discussion}

\subsection{Areas of Greatest Improvement in Urban and Agricultural Systems}

\subsubsection{Urban Systems: All Water is a (Re)Usable Resource}

Meeting the challenges of water resources sustainability increasingly involves ... applying innovative approaches to conjunctive use of groundwater, surface water, artificial recharge, and water reuse. -Alley and Leake [80]

Managing water resource sustainability requires considering water in all states and forms as potential resources for use and reuse. Improving use efficiency, capture, and reuse of these non-traditional water resources is more critical in water stressed regions, and those which are expected to become stressed due to climate change or population growth. Treating wastewater is a key part of solving water scarcity [16]. As climate change makes dry regions drier [112,113], the need for water capture and reuse intensifies in areas with increasing water stress.

There are two key points when considering all water as resources; first, not all applications require the same quality water, and second, not all "used" water requires the same level of treatment before it can be reused. Treatment before and treatment after of the combined water stream uses unnecessary amounts of energy and effort [91]. Incentivizing a selective system of treatment and reuse requires that water be priced appropriately. Water must be considered an economic good to account for its competing uses [85], where the price depends on availability and quality. To encourage treatment and reuse, the value of water should equal the cost of treating source water to necessary standards.

Green infrastructure and stormwater capture are not fully utilized in both developing and developed regions. Excess water during rain events can be harvested and stored for use in dry periods [91]. Depending on the level of existing infrastructure and water application purposes, the scale of water capture and distribution can range from household to neighborhood to city. In many developing regions, small scale capture is recommended at the household level using storage tanks or infiltration ponds in conjunction with hand pumps for recovery [114]. Increased capture and use of all available water resources will significantly reduce water stress, especially during dry seasons and periods of drought.

\subsubsection{Agricultural Systems: Crop Water Productivity}

Improvements in crop water productivity can result in commensurately large decreases in water use because agriculture accounts for the largest quantity of water use. With water use efficiency ranging between $10 \%$ and $30 \%$ for rainfed and between $40 \%$ and $95 \%$ for irrigated agriculture $[22,115,116]$, there is nearly always opportunity for improvement. Methods for improved on-farm agricultural water management include supplementing rainfed crops, irrigation scheduling, and efficient irrigation methods [117]. At the national or global scale, agricultural water use efficiency can be improved by growing more food in high water productivity regions and exporting to less productive regions [118]. Irrigation (or electricity) subsidies should target regions with sustainable water sources, or should couple incentives for high efficiency irrigation systems and low water-requirement crops. As water demands increase in the developing world, irrigation reliability is expect to decline from 0.79 (out of 1.0) in 2005 
to 0.71 in 2025 [119]. In areas where groundwater use is unsustainable, improving efficiency (and decreasing total extraction) allows production to continue longer into the future [120].

The use of technology to inform irrigation scheduling can save water, and also increase crop yields compared to over-irrigation [121]. The estimated benefits of irrigation scheduling will vary by method and location. Methods for irrigation scheduling include using soil moisture sensors and incorporating weather forecast data. Soil moisture sensors or tensiometers indicate soil wetness conditions, and can be compared to plant moisture requirements. Sensor informed agriculture water savings range from $18 \%$ to $50 \%$ [122]. Crop water production can be further improved by combining irrigation scheduling with farm management techniques including mulching, reducing soil hydrophobicity, and the use of wastewater [123]. Instrument cost is a primary barrier in both developing and developed regions. The technology must be designed within the budget of the intended farmers, and/or should be subsidized by the government.

In regions where water is the limiting factor to production instead of land, increases in water use efficiency may allow farmers to irrigate more land. While this is arguably not a SWM solution because it does not reduce the total amount of water used for irrigation [124], it does increase the crop water productivity of the region. In cases were over-irrigation results in runoff and water supply for downstream users, irrigation reduction may in fact reduce water availability to these users, and should be considered in the overall management strategy [125].

\subsection{Relevance of Country Development Status}

This review highlights several differences as well as similarities between developing and developed nation SWM objectives (Table 2), challenges, and solutions (Tables 3 and 4). The differences lie in the context and level of development, and not in the definition of sustainability. The model selected for SWM evaluation typically varies to accommodate local infrastructure and economic conditions, but still maintains the objectives of sustainable development.

For urban water systems, equitable and reliable supply is the objective in developed and developing regions. Water stress and aging infrastructure are challenges faced around the world. Developing nations may face additional challenges including intermittent electricity and disparities in access to water delivery or built infrastructure. Indeed, the focus of SWM in developing countries is on providing equitable and reliable water supply, while developed nations may focus on water reuse and system longevity (Table 2). In addition, many developed regions now strive to have water systems that mimic natural ecosystems [75]. Water system evaluation may also include a demand management component in developed regions. Conversely, this metric is irrelevant in regions where people are not yet receiving the recommended amount of water, for example more than half of the population of the Middle East, as determined by the Islamic Network on Water Resources Development and Management [16].

Evaluation models and opportunities in agriculture are most sensitive to whether the farm is rainfed or irrigated, and what technology and information the farmer has access to. In developing nations, increasing crop productivity and equitable water allocation is critical. However, as we have learned from the Green Revolution in South Asia, increasing productivity at the expense of natural resources is not a sustainable solution. In rainfed agriculture, methods for improving yields should include supplemental irrigation during critical growth periods, and on-farm management practices that improve soil moisture 
holding capacity. In developed nations with high levels of food security, increasing resource use efficiency should be a priority. The use of soil and plant sensors to inform irrigation scheduling must be part of the solution, as well as switching to more efficient irrigation technologies.

The literature on environmental water management is dominated by developed region case studies and models where water management needs have been met and sustainability emerges as a priority. We note the presence of environmental objectives in both urban and agricultural development (Table 2). Conversely, in developing regions, the objectives for environmental water management are presented by two contrasting sides. The first follows the order of the Hierarchy of Water Management Needs (Table 1), asserting that until individual and community water needs are met, environmental sustainability is not a priority. Larsen and Gujer [8] stated "sustainable development is only possible in the absence of extreme poverty ... In areas with a lack of safe drinking water, biological diversity and other ecosystem requirements will not be given any priority." In alignment with this thinking, meaningful protection of the environment is generally not integrated into developing nation policy because it is considered anti-development.

It is irresponsible to allow damage to resources that will ultimately be required for a population to continue developing. The second perspective, which is held by communities who depend heavily on the natural environment for their livelihoods, prioritizes sustainable resource use and protection of the environment regardless of economic development level. The Southern African Development Community is an example of a progressive group regarding environmental sustainability. They maintain that poverty reduction does not need to compromise environmental health and services. This perspective will grow as further evidence of economic and social development coupled with environmental protection is successfully documented. All regions can have the intent of SWM, while practices may vary with geography and economic capabilities.

\subsection{Limitations}

Limitations of this study include: (1) the exclusive scope of urban, agricultural, and natural systems; (2) the challenge of obtaining municipal and other types of non-peer reviewed documents; and (3) omission of relevance of country geography, climate, and other factors. While urban and agricultural systems account for over $80 \%$ of global water consumption, other water uses such as industrial and recreational can be significant in some countries or local regions. Future reviews of other water uses would be complementary to this one, and provide value in improving water management practices across sectors. Much of the relevant literature, especially for urban water management, may include white papers, municipal reports, and other documents which are not typically available in academic databases. This review likely overlooked numerous documents describing SWM assessments, practices, challenges, and solutions. Future reviews would benefit from a more thorough search for these reports. Lastly, the scope of this paper did not include a synthesis of how country geography, climate, and other factors affect SWM practices. Future studies may focus on a number of factors to illustrate why SWM practices can differ in proximal nations or be similar in distant nations; relevant endogenous factors may include in-country distribution of wealth and resources, socio-cultural traditions, and political stability, while exogenous factors may include climate, geology, and a more detailed look at historical and present inter-country conflict. 


\section{Conclusions}

SWM of urban, agricultural, and environmental systems is integral to continued development. Numerous models and metrics exist for evaluating sustainable management practices. Improvements to these methods should focus on the interconnectedness of social and physical systems using robust quantitative metrics. Urban water management in developing regions faces challenges of equitable delivery, especially under rapid urban population growth. Sustainable management plans should focus on continued improvements in stakeholder involvement and infrastructure in developing regions, and on water reclamation and reuse in developed regions. Water reuse will reduce stress during drought periods, though technology adoption cost and risks are still barriers in both developing and developed nations. Improvements to crop water productivity can benefit all sectors of water users discussed in this article by reducing competition between the agricultural sector and urban and environmental users. Crop water production in irrigated areas can be improved with changes in crop water allocation and adoption of efficient irrigation and on-farm technologies, while rainfed agricultural areas will benefit from supplemental irrigation. Maintaining sustainable water supply in natural systems can be seen to conflict with development practices if only looking at the near-term future. Long-term economic development is clearly linked to environmental system health, evidenced by developed country focus on restoration and protection of water resources. In application, decisions informed by the estimated value of ecosystem services may be used to set thresholds for environmental degradation, in the context of social and economic development goals. SWM will vary with geography and economic capabilities, though all regions can manage water resources in a way that supports sustainable social, economic, and environmental development.

\section{Acknowledgments}

This work was supported by the Advanced Consortium on Cooperation, Conflict and Complexity, The Columbia Water Center, and the Earth Institute Fellowship program at Columbia University. We thank two anonymous reviewers for their constructive comments, and Madhura Karnik and Kuan-Lin Liu for assembling the preliminary collection of literature.

\section{Authors Contribution}

Katherine Alfredo contributed expertise on the evaluation metrics, urban water management challenges and solutions, and water reuse. Joshua Fisher provided substantive input to synthesize the water-based measures and tools with existing sustainable development metrics, theories and toolkits.

\section{Conflicts of Interest}

The authors declare no conflict of interest. The founding sponsors had no role in the design of the study; in the collection, analyses, or interpretation of data; in the writing of the manuscript, and in the decision to publish the results. 


\section{References}

1. Rio+20 from a Water Perspective. Available online: http://www.unwater.org/news-events/ news-details/en/c/207616/ (accessed on 1 February 2014).

2. United Nations World Commission on Environment and Development (UN WCED). Our Common Future: Report of the World Commission on Environment and Development; Document A/42/427; United Nations: New York, NY, USA, 1987.

3. Mays, L. Water Resources Sustainability; McGraw-Hill Professional: New York, NY, USA, 2006.

4. Loucks, D.; Gladwell, J. Sustainability Criteria for Water Resource Systems; Cambridge University Press: Cambridge, UK, 1999.

5. Alley, W.; Reilly, T.; Franke, O. Sustainability of Ground-Water Resources; US Department of the Interior, US Geological Survey: Denver, CO, USA, 1999.

6. United Nations. Agenda 21. In Proceedings of the United Nations Conference on Environment \& Development, Rio de Janero, Brazil, 3-14 June 1992.

7. Mihelcic, J.R.; Crittenden, J.C.; Small, M.J.; Shonnard, D.R.; Hokanson, D.R.; Zhang, Q.; Chen, H.; Sorby, S.A.; James, V.U.; Sutherland, J.W.; et al. Sustainability science and engineering: The emergence of a new metadiscipline. Environ. Sci. Technol. 2003, 37, 5314-5324.

8. Larsen, T.; Gujer, W. The concept of sustainable urban water management. Water Sci. Technol. 1997, 35, 3-10.

9. Gleick, P. Basic water requirements for human activities: Meeting basic needs. Water Int. 1996, 21, 83-92.

10. Ecosystems and Human Well-Being: Wetlands and Water Synthesis; Millennium Ecosystem Assessment: Washington, DC, USA, 2005.

11. Melloul, A.J.; Collin, M.L. Harmonizing water management and social needs: A necessary condition for sustainable development. The case of Israel's coastal aquifer. J. Environ. Manag. 2003, 67, 385-394.

12. FAO AQUASTAT: Water withdrawal by sector, around 2006. Available online: www.fao.org/nr/water/aquastat/globalmaps/AquastatWorldDataEng_20121214_Withdrawal.pdf (accessed on 1 February 2014).

13. McDonald, R.I.; Green, P.; Balk, D.; Fekete, B.M.; Revenga, C.; Todd, M.; Montgomery, M. Urban growth, climate change, and freshwater availability. Proc. Natl. Acad. Sci. USA 2011, 108, 6312-6317.

14. Vairavamoorthy, K.; Akinpelu, E. Design of sustainable water distribution systems in developing countries. ASCE World Water Congr. 2001, 44, 1-10.

15. Rahmato, D. Water Resource Development in Ethiopia: Issues of Sustainability and Participation; Forum for Social Studies: Addis Ababa, Ethiopia, 1999.

16. Al-Qurashi, A.; Husain, T. Sustainable Water Resources Development Plan for the Middle-East Countries. In Proceedings of the ASCE World Water Congress, Orlando, FL, USA, 20-24 May 2001.

17. Jiang, Y. China's water scarcity. J. Environ. Manag. 2009, 90, 3185-3196.

18. Gleick, P. Water, drought, climate change, and conflict in Syria. Weather Clim. Soc. 2014, 6, 331-340. 
19. Conde, G. An indicator of conflict? Water in between Turkey, Syria and Iraq. Reg. Cohes. 2014, 4, 81-100.

20. Inocencio, A.; Kikuchi, M.; Tonosaki, M.; Maruyama, A.; Merrey, D.; Sally, H.; de Jong, I. Costs and Performance of Irrigation Projects: A Comparison of Sub-Saharan Africa and Other Developing Regions; International Water Management Institute: Colombo, Sri Lanka, 2007.

21. Russo, T.; Devineni, N.; Lall, U. Assessment of Agricultural Water Management in Punjab, India Using Bayesian Methods. In Sustainability of Integrated Water Resources Management: Water Governance, Climate and Ecohydrology; Setegn, S., Donoso, M., Eds.; Springer: Berlin, Germany, 2014.

22. Araus, J. The problems of sustainable water use in the Mediterranean and research requirements for agriculture. Ann. Appl. Biol. 2004, 144, 259-272.

23. Khan, S.; Tariq, R.; Yuanlai, C.; Blackwell, J. Can irrigation be sustainable? Agric. Water Manag. 2006, 80, 87-99.

24. Tiwari, P.C.; Joshi, B. Environmental changes and sustainable development of water resources in the Himalayan headwaters of India. Water Resour. Manag. 2011, 26, 883-907.

25. Benzerra, A.; Cherrared, M.; Chocat, B.; Cherqui, F.; Zekiouk, T. Decision support for sustainable urban drainage system management: A case study of Jijel, Algeria. J. Environ. Manag. 2012, 101, 46-53.

26. Daibes, F. Towards sustainable development in the water sector: A perspective from Palestine. Water Sci. Technol. 2000, 42, 81-86.

27. Antoniadis, A.; Takavakoglou, V.; Zalidis, G.; Darakas, E.; Poulios, I. Municipal wastewater treatment by sequential combination of photocatalytic oxidation with constructed wetlands. Catal. Today 2010, 151, 114-118.

28. Al-Jayyousi, O. Greywater reuse: Towards sustainable water management. Desalination 2003, 156, 181-192.

29. Voza, D.; Vukovic, M.; Carlson, L.; Djordjević, D.B. International water conflict and cooperation: The role of power relations among. Int. J. Humanit. Soc. Sci. 2012, 2, 56-66.

30. De Stefano, L.; Edwards, P.; de Silva, L.; Wolf, A.T. Tracking cooperation and conflict in international basins: Historic and recent trends. Water Policy 2010, 12, 871-884.

31. Stark1, M.; Brunner, N.; Lo, E.; Mart1, L. A planning-oriented sustainability assessment framework for peri-urban water management in developing countries. Water Res. 2013, 47, 1-9.

32. Pearson, L.J.; Coggan, A.; Proctor, W.; Smith, T.F. A sustainable decision support framework for urban water management. Water Resour. Manag. 2009, 24, 363-376.

33. Postel, S. Pillar of Sand: Can the Irrigation Miracle Last?; W.W. Norton \& Company: New York, NY, USA, 1999.

34. Pereira, L.S.; Cordery, I.; Iacovides, I. Improved indicators of water use performance and productivity for sustainable water conservation and saving. Agric. Water Manag. 2012, 108, 39-51.

35. Kumar, M.D.; Scott, C.A.; Singh, O.P. Can India raise agricultural productivity while reducing groundwater and energy use? Int. J. Water Resour. Dev. 2013, 29, 557-573.

36. Dinar, A.; Mody, J. Irrigation water management policies: Allocation and pricing principles and implementation experience. Nat. Resour. Forum 2004, 28, 112-122. 
37. Johansson, R.C.; Tsur, Y.; Roe, T.L.; Doukkali, R.; Dinar, A. Pricing irrigation water: A review of theory and practice. Water Policy 2002, 4, 173-199.

38. Rockström, J.; Barron, J. Water productivity in rainfed systems: Overview of challenges and analysis of opportunities in water scarcity prone savannahs. Irrig. Sci. 2007, 25, 299-311.

39. Biazin, B.; Sterk, G.; Temesgen, M.; Abdulkedir, A.; Stroosnijder, L. Rainwater harvesting and management in rainfed agricultural systems in sub-Saharan Africa-A review. Phys. Chem. Earth Parts A/B/C 2012, 47-48, 139-151.

40. Fox, P.; Rockström, J. Water-harvesting for supplementary irrigation of cereal crops to overcome intra-seasonal dry-spells in the Sahel. Phys. Chem. Earth 2000, 25, 289-296.

41. Oweis, T.; Hachum, A. Supplemental Irrigation: A Highly Efficiency Water Use Practice; International Center for Agricultural Research in the Dry Areas (ICARDA): Aleppo, Syria, 2012.

42. Schuyt, K.D. Economic consequences of wetland degradation for local populations in Africa. Ecol. Econ. 2005, 53, 177-190.

43. Hirji, R.; Mackay, H.; Maro, P. Defining and Mainstreaming Environmental Sustainability in Water Resources Management in Southern Africa-A Summary; SADC, IUCN, SARDC, World Bank: Washington, DC, USA, 2002.

44. Dixon, A.B.; Wood, A.P. Wetland cultivation and hydrological management in eastern Africa: Matching community and hydrological needs through sustainable wetland use. Nat. Resour. Forum 2003, 27, 117-129.

45. White, S.; Fane, S. Designing cost effective Water Demand Management Programs in Australia. Water Sci. Technol. 2002, 46, 225-232.

46. Dawadi, S.; Ahmad, S. Evaluating the impact of demand-side management on water resources under changing climatic conditions and increasing population. J. Environ. Manag. 2013, 114, 261-275.

47. Marlow, D.R.; Moglia, M.; Cook, S.; Beale, D.J. Towards sustainable urban water management: A critical reassessment. Water Res. 2013, 47, 7150-7161.

48. Le Maitre, D.; Colvin, C.; Maherry, A. Water resources in the Klein Karoo: The challenge of sustainable development in a water-scarce area. S. Afr. J. Sci. 2009, 105, 39-48.

49. Schaible, G.D.; Aillery, M.P. Water Conservation in Irrigated Agriculture: Trends and Challenges in the Face of Emerging Demands; US Department of Agriculture, Economic Research Service: Washington, DC, USA, 2012.

50. Ward, F.A.; Michelsen, A.M.; DeMouche, L. Barriers to water conservation in the Rio Grande Basin1. J. Am. Water Resour. Assoc. 2007, 43, 237-253.

51. Costanza, R.; D'Arge, R.; de Groot, R.; Farber, S. The value of the world's ecosystem services and natural capital. Nature 1997, 387, 253-260.

52. Buckle, J.S. Water demand management-Philosophy or implementation? Water Sci. Technol. 2000, 4, 25-32.

53. Marks, J.; Zadoroznyj, M. Managing sustainable urban water reuse: structural context and cultures of trust. Soc. Nat. Resour. 2005, 18, 557-572.

54. Grant, S.B.; Saphores, J.-D.; Feldman, D.L.; Hamilton, A.J.; Fletcher, T.D.; Cook, P.L.M.; Stewardson, M.; Sanders, B.F.; Levin, L.A.; Ambrose, R.F.; et al. Taking the "waste" out of “wastewater" for human water security and ecosystem sustainability. Science 2012, 337, 681-686. 
55. Dixon, A.; Butler, D.; Fewkes, A. Water saving potential of domestic water reuse systems using greywater and rainwater combination. Water Sci. Technol. 1999, 39, 25-32.

56. Ellis, J.B. Sustainable surface water management and green infrastructure in UK urban catchment planning. J. Environ. Plan. Manag. 2013, 56, 24-41.

57. Pizzol, M.; Scotti, M.; Thomsen, M. Network Analysis as a tool for assessing environmental sustainability: Applying the ecosystem perspective to a Danish water management system. J. Environ. Manag. 2013, 118, 21-31.

58. Georgiou, P.E.; Papamichail, D.M. Optimization model of an irrigation reservoir for water allocation and crop planning under various weather conditions. Irrig. Sci. 2008, 26, 487-504.

59. Playán, E.; Mateos, L. Modernization and optimization of irrigation systems to increase water productivity. Agric. Water Manag. 2006, 80, 100-116.

60. Rajagopal-Durbin, A.; Durbin, T.J. Wells are not always water follies: Sustainable groundwater policies for the American west. Water Policy 2008, 10, 145-164.

61. Chapin, F.S.; Carpenter, S.R.; Kofinas, G.P.; Folke, C.; Abel, N.; Clark, W.C.; Olsson, P.; Smith, D.M.S.; Walker, B.; Young, O.R.; et al. Ecosystem stewardship: Sustainability strategies for a rapidly changing planet. Trends Ecol. Evol. 2010, 25, 241-249.

62. Horrigan, L.; Lawrence, R.; Walker, P. How sustainable agriculture can address the environmental and human health harms of industrial agriculture. Environ. Health Perspect. 2002, 110, 445-456.

63. Gleick, P.; Chaleki, E.; Wong, A. Measuring Water Well-Being: Water Indicators and Indices. In The World's Water 2002-2003: The Biennial Report on Freshwater Resources; Island Press: Washington, DC, USA, 2002.

64. Ness, B.; Urbel-Piirsalu, E.; Anderberg, S.; Olsson, L. Categorising tools for sustainability assessment. Ecol. Econ. 2007, 60, 498-508.

65. Singh, R.K.; Murty, H.R.; Gupta, S.K.; Dikshit, A.K. An overview of sustainability assessment methodologies. Ecol. Indic. 2009, 9, 189-212.

66. Mori, K.; Christodoulou, A. Review of sustainability indices and indicators: Towards a new city sustainability index (CSI). Environ. Impact Assess. Rev. 2012, 32, 94-106.

67. Hellström, D.; Jeppsson, U.; Kärrman, E. A framework for systems analysis of sustainable urban water management. Environ. Impact Assess. 2000, 20, 311-321.

68. Juwana, I.; Muttil, N.; Perera, B.J.C. Indicator-based water sustainability assessment-A review. Sci. Total Environ. 2012, 438, 357-371.

69. Lawrence, P.R.; Meigh, J.; Sullivan, C. The Water Poverty Index: An International Comparison; Keele University: Staffordshire, UK, 2002.

70. The Canadian Water Resources Sustainability Index (CWSI); Policy Research Initiative: Ottawa, ON, Canada, 2007.

71. Hsu, A.; Emerson, J.; Levy, M.; de Sherbinin, A.; Johnson, L.; Malik, O.; Jaiteh, M. Environmental Performance Index; Yale Center for Environmental Law and Policy: New Haven, CT, USA, 2014.

72. Chaves, H.M.L.; Alipaz, S. An integrated indicator based on basin hydrology, environment, life, and policy: The watershed sustainability index. Water Resour. Manag. 2006, 21, 883-895.

73. Ewing, B.; Reed, A.; Galli, A.; Kitzes, J.; Wackernagel, M. Calculation Methodology for the National Footprint Accounts, 2010 Edition; Global Footprint Network: Oakland, CA, USA, 2010. 
74. Hoekstra, A.; Chapagain, A.; Aldaya, M.; Mekonnen, M. The Water Footprint Assessment Manual: Setting the Global Standard; Earthscan: London, UK, 2011.

75. Ulanowicz, R.E.; Goerner, S.J.; Lietaer, B.; Gomez, R. Quantifying sustainability: Resilience, efficiency and the return of information theory. Ecol. Complex. 2009, 6, 27-36.

76. Bagheri, A.; Hjorth, P. A framework for process indicators to monitor for sustainable development: Practice to an urban water system. Environ. Dev. Sustain. 2006, 9, 143-161.

77. Chung, E.-S.; Lee, K.S. Prioritization of water management for sustainability using hydrologic simulation model and multicriteria decision making techniques. J. Environ. Manag. 2009, 90, 1502-1511.

78. Lee, C. The determination of safe yield of underground reservoirs of the closed basin type. Trans. Am. Soc. Civ. Eng. 1915, 78, 148-251.

79. Todd, D. Ground Water Hydrology; John Wiley: New York, NY, USA, 1959.

80. Alley, W.; Leake, S. The journey from safe yield to sustainability. Ground Water 2004, 42, 12-16.

81. Bredehoeft, J. Safe yield and the water budget myth. Ground Water 1997, 35, 929.

82. Sophocleous, M. Managing water resources systems: Why "safe yield" is not sustainable. Ground Water 1997, 35, 561.

83. Bredehoeft, J.; Durbin, T. Ground water development-The time to full capture problem. Ground Water 2009, 47, 506-14.

84. Zhou, Y. A critical review of groundwater budget myth, safe yield and sustainability. J. Hydrol. 2009, 370, 207-213.

85. Mwanza, D.D. Water for sustainable development in Africa. In The World Summit on Sustainable Development; Springer: Berlin, Germany, 2005.

86. Peter, G.; Nkambule, S.E. Factors affecting sustainability of rural water schemes in Swaziland. Phys. Chem. Earth Parts A/B/C 2012, 50-52, 196-204.

87. Brown, R.R.; Farrelly, M.A. Delivering sustainable urban water management: A review of the hurdles we face. Water Sci. Technol. 2009, 59, 839-846.

88. Töpfer, K. Balancing competing water uses-A necessity for sustainable development. Water Sci. Technol. 2003, 47, 11-16.

89. Mbilinyi, B.P.; Tumbo, S.D.; Mahoo, H.F.; Senkondo, E.M.; Hatibu, N. Indigenous knowledge as decision support tool in rainwater harvesting. Phys. Chem. Earth Parts A/B/C 2005, 30, 792-798.

90. The World's Women 2010: Trends and Statistics; United Nations Department of Economic and Social Affairs (UN DESA): New York, NY, USA, 2010.

91. Niemczynowicz, J. Urban hydrology and water management-Present and future challenges. Urban Water 1999, 1, 1-14.

92. Rahman, M.A.; Ahsan, S.; Kaneco, S.; Katsumata, H.; Suzuki, T.; Ohta, K. Wastewater treatment with multilayer media of waste and natural indigenous materials. J. Environ. Manag. 2005, 74, 107-110.

93. Angin, I. An investigation on natural wastewater treatment system and re-usability of wastewater in irrigation. J. Sustain. Agric. 2007, 31, 83-90.

94. Kivaisi, A.K. The potential for constructed wetlands for wastewater treatment and reuse in developing countries: A review. Ecol. Eng. 2001, 16, 545-560. 
95. Rockstrom, J.; Barron, J.; Fox, P. Water Productivity in Rain Fed Agriculture: Challenges and Opportunities for Smallholder Farmers in Drought-Prone Tropical Agro-Ecosystems. In Water Productivity in Agriculture: Limits and Opportunities for Improvement; CABI: Wallingford, UK, 2003.

96. Falcon, W.; Naylor, R. Rethinking food security for the twenty-first century. Am. J. Agric. Econ. 2005, 87, 1113-1127.

97. Khan, S.; Hanjra, M.A. Footprints of water and energy inputs in food production-Global perspectives. Food Policy 2009, 34, 130-140.

98. Tabor, J.A. Improving crop yields in the Sahel by means of water-harvesting. J. Arid Environ. 1995, 30, 83-106.

99. Ngigi, S.N.; Savenije, H.H.G.; Gichuki, F.N. Land use changes and hydrological impacts related to up-scaling of rainwater harvesting and management in upper Ewaso Ng'iro river basin, Kenya. Land Use Policy 2007, 24, 129-140.

100. Lundin, M.; Molander, S.; Morrison, G. A set of indicators for the assessment of temporal variations in the sustainability of sanitary systems. Water Sci. Technol. 1999, 39, 235-242.

101. World Water Development Report (WWDR3) Water in a Changing World; The United Nations Educational, Scientific and Cultural Organization (UNESCO): Paris, France, 2009.

102. Wichelns, D.; Oster, J.D. Sustainable irrigation is necessary and achievable, but direct costs and environmental impacts can be substantial. Agric. Water Manag. 2006, 86, 114-127.

103. Khan, S.; Hanjra, M. Sustainable land and water management policies and practices: A pathway to environmental sustainability in large irrigation systems. L. Degrad. Dev. 2008, 487, 469-487.

104. Tilman, D.; Cassman, K.G.; Matson, P.A.; Naylor, R.; Polasky, S. Agricultural sustainability and intensive production practices. Nature 2002, 418, 671-677.

105. Pimentel, D.; Pimentel, M. Food, Energy and Society; Colorado University Press: Niwot, CO, USA, 1996.

106. Smakhtin, V.; Revenga, C.; Döll, P. A pilot global assessment of environmental water requirements and scarcity. Water Int. 2004, 29, 307-317.

107. Richter, B.D.; Mathews, R.; Harrison, D.; Wigington, R. Ecologically sustainable water management: Managing river flows for ecological integrity. Ecol. Appl. 2003, 13, 206-224.

108. Poff, N.L.; Richter, B.D.; Arthington, A.H.; Bunn, S.E.; Naiman, R.J.; Kendy, E.; Acreman, M.; Apse, C.; Bledsoe, B.P.; Freeman, M.C.; et al. The ecological limits of hydrologic alteration (ELOHA): A new framework for developing regional environmental flow standards. Freshw. Biol. 2010, 55, 147-170.

109. Acreman, M.C.; Dunbar, M.J. Defining environmental river flow requirements-A review. Hydrol. Earth Syst. Sci. 2004, 8, 861-876.

110. Arthington, A.H.; Bunn, S.E.; Poff, N.L.; Naiman, R.J. The challenge of providing environmental flow rules to sustain river ecosystems. Ecol. Appl. 2006, 16, 1311-1318.

111. Marshall, R.M.; Robles, M.D.; Majka, D.R.; Haney, J.A. Sustainable water management in the southwestern United States: Reality or rhetoric? PLoS One 2010, 5, doi:10.1371/journal.pone.0011687.

112. Chou, C.; Neelin, J.D.; Chen, C.-A.; Tu, J.-Y. Evaluating the "rich-get-richer" mechanism in tropical precipitation change under global warming. J. Clim. 2009, 22, 1982-2005. 
113. Held, I.; Soden, B. Robust responses of the hydrological cycle to global warming. J. Clim. 2006, $19,5686-5699$.

114. Malley, Z.J.U.; Taeb, M.; Matsumoto, T.; Takeya, H. Environmental sustainability and water availability: Analyses of the scarcity and improvement opportunities in the Usangu plain, Tanzania. Phys. Chem. Earth 2009, 34, 3-13.

115. Causapé, J.; Quílez, D.; Aragüés, R. Irrigation efficiency and quality of irrigation return flows in the Ebro River Basin: An overview. Environ. Monit. Assess. 2006, 117, 451-461.

116. Falkenmark, M.; Rockström, J. The new blue and green water paradigm: Breaking new ground for water resources planning and management. J. Water Resour. Plan. Manag. 2006, 132, 129-132.

117. Scanlon, B.R.; Jolly, I.; Sophocleous, M.; Zhang, L. Global impacts of conversions from natural to agricultural ecosystems on water resources: Quantity versus quality. Water Resour. Res. 2007, 43, doi:10.1029/2006WR005486.

118. Yang, H.; Wang, L.; Abbaspour, K.C.; Zehnder, A.J.B. Virtual water trade: An assessment of water use efficiency in the international food trade. Hydrol. Earth Syst. Sci. 2006, 10, 443-454.

119. Rosegrant, M.; Cai, X. Global water demand and supply projections global water demand and supply projections Part 2. Results and prospects to 2025. Water Int. 2002, 27, 170-182.

120. Steward, D.R.; Bruss, P.J.; Yang, X.; Staggenborg, S.A.; Welch, S.M.; Apley, M.D. Tapping unsustainable groundwater stores for agricultural production in the high plains aquifer of Kansas, projections to 2110. Proc. Natl. Acad. Sci. USA 2013, 110, E3477-E3486.

121. Irmak, S. Plant Growth and Yield as Affected by Wet Soil Conditions due to Flooding or Over-Irrigation; University of Nebraska-Lincoln Extension: Lincoln, NE, USA, 2014.

122. Van Iersel, M.; Seymour, R.M.; Chappell, M.; Watson, F.; Dove, S. Soil moisture sensor-based irrigation reduces water use and nutrient leaching in a commercial nursery. Proc. South. Nurs. Assoc. Res. Conf. 2009, 54, 17-21.

123. Stroosnijder, L.; Moore, D.; Alharbi, A.; Argaman, E.; Biazin, B.; van den Elsen, E. Improving water use efficiency in drylands. Curr. Opin. Environ. Sustain. 2012, 4, 497-506.

124. Scott, C.A. The water-energy-climate nexus: Resources and policy outlook for aquifers in Mexico. Water Resour. Res. 2011, 47, doi:10.1029/2011WR010805.

125. Ward, F.; Pulido-Velazquez, M. Water conservation in irrigation can increase water use. Proc. Natl. Acad. Sci. USA 2008, 105, 18215-18220.

(C) 2014 by the authors; licensee MDPI, Basel, Switzerland. This article is an open access article distributed under the terms and conditions of the Creative Commons Attribution license (http://creativecommons.org/licenses/by/4.0/). 